\title{
Quantitative assessment on soil enzyme activities of heavy metal contaminated soils with various soil properties
}

\author{
Yu Xian ${ }^{\mathrm{a}, \mathrm{b}}$, Meie Wang ${ }^{\mathrm{a}}$, Weiping Chen ${ }^{\mathrm{a}, *}$ \\ a State Key Laboratory of Urban and Regional Ecology, Research Center for Eco-Environmental Sciences, Chinese Academy of Sciences, Beijing 100085, China \\ ${ }^{\mathrm{b}}$ Qingdao Agricultural University, Qingdao 266109, China
}

\section{H I G H L I G H T S}

- Joint effects of heavy metals and soil properties on soil enzyme activities were determined.

- Arylsulfatase could be used as an indicator to study the toxicity of heavy metals.

- Changes of arylsulfatase activity with SOM content fitted well an exponential model.

- The model illustrated the offset of SOM to heavy metal toxicity on soil enzymes activities.

\section{A R T I C L E I N F O}

\section{Article history:}

Received 26 May 2014

Received in revised form 9 December 2014

Accepted 18 December 2014

Available online 10 January 2015

Handling Editor: Tamara S. Galloway

\section{Keywords:}

Soil heavy metal toxicity

Soil enzyme activity

Soil properties

Quantitative model

Ecological risk assessment

\begin{abstract}
A B S T R A C T
Soil enzyme activities are greatly influenced by soil properties and could be significant indicators of heavy metal toxicity in soil for bioavailability assessment. Two groups of experiments were conducted to determine the joint effects of heavy metals and soil properties on soil enzyme activities. Results showed that arylsulfatase was the most sensitive soil enzyme and could be used as an indicator to study the enzymatic toxicity of heavy metals under various soil properties. Soil organic matter (SOM) was the dominant factor affecting the activity of arylsulfatase in soil. A quantitative model was derived to predict the changes of arylsulfatase activity with SOM content. When the soil organic matter content was less than the critical point A (1.05\% in our study), the arylsulfatase activity dropped rapidly. When the soil organic matter content was greater than the critical point A, the arylsulfatase activity gradually rose to higher levels showing that instead of harm the soil microbial activities were enhanced. The SOM content needs to be over the critical point $\mathrm{B}$ ( $2.42 \%$ in our study) to protect its microbial community from harm due to the severe $\mathrm{Pb}$ pollution ( $500 \mathrm{mg} \mathrm{kg}^{-1}$ in our study). The quantitative model revealed the pattern of variation of enzymatic toxicity due to heavy metals under various SOM contents. The applicability of the model under wider soil properties need to be tested. The model however may provide a methodological basis for ecological risk assessment of heavy metals in soil.
\end{abstract}

(c) 2014 Elsevier Ltd. All rights reserved.

\section{Introduction}

Soil plays important roles in supporting primary productivity, modulating nutrient flows, and promoting the wellbeing of a terrestrial eco-system (Haberern, 1992; Doran et al., 1997). The ecosystem health may be harmed when toxicants such as heavy metals accumulate in the soils and adversely affect the soil microorganisms. Knowledge of their bioavailability is imperative in assessing the environmental and ecological risks of soil-borne heavy metals. Soil enzyme activities that measure the collective metabolism of the soil microbial community can be used to reflect

\footnotetext{
* Corresponding author. Tel./fax: +86 1062843981.

E-mail address: wpchen@rcees.ac.cn (W. Chen).
}

the ecological health of terrestrial ecosystems under the influence of soil heavy metal pollution (Badiane et al., 2001; Filip, 2002; Hinojosa et al., 2004; Chaperon and Sauve, 2007; Khan et al., 2007).

Soil enzyme activities such as those of arylsulfatase, $\beta$-glucosidase, acid and alkaline phosphatase, protease, urease, cellulase, dehydrogenase, protease, and invertase are sensitive to the presence of heavy metals (Kunito et al., 2001; Effron et al., 2004; Oliveira and Pampulha, 2006; Wang et al., 2008). The doseresponse relationships however vary considerably with the properties of the soils. Doelman and Haanstra (1986) showed that the ecological dose at $50 \%$ harm $\left(\mathrm{ED}_{50}\right)$ for $\mathrm{Cd}, \mathrm{Cr}, \mathrm{Cu}, \mathrm{Ni}, \mathrm{Pb}$ and $\mathrm{Zn}$ varied with soil types. For examples, $\mathrm{ED}_{50}$ of $\mathrm{Pb}$ was $1590,2870,8130$, 1340 , and $7050 \mathrm{mg} \mathrm{kg}^{-1}$ in sand, sandy loam, silty loam, clay, and sandy peat soils. 
The metals' bioavailability in soils might be quantitatively related, in addition to metal contents, to a soil's $\mathrm{pH}$, organic matter and clay contents. Bioavailable $\mathrm{Cd}, \mathrm{Cu}, \mathrm{Ni}, \mathrm{Pb}$ and $\mathrm{Zn}$ contents of soils were predicted mathematically by soils' $\mathrm{pH}$, total metal and organic matter contents, resulting in $R^{2}$ between 0.54 and 0.91 (Sauve et al., 2000; Carlon et al., 2004). The available metals increased inversely with soils' $\mathrm{pH}$ and decreased inversely with soils' organic contents (D'Ascoli et al., 2006). In fact, organic amendments often enhanced enzyme activities of heavy metal contaminated soils (Mora et al., 2005; Karaca et al., 2006; Baker et al., 2011). The $\mathrm{ED}_{50}$ of $\mathrm{Cd}$ and $\mathrm{Ni}$ on urease and phosphatase activities of receiving soil increased rather than decreased when the heavy metal laden sewage sludge was land applied (Moreno et al., 2003).

It is known that the enzyme activities of heavy metal contaminated soils are affected by properties of the soils. However, the quantitative cause-effect relationship between the activities of key enzymes and soil heavy metal content is still unclear, hindering the use of soil enzyme activities in assessment of heavy metal bioavailability. In this research, we tested the activities of six enzymes, namely invertase, urease, arylsulfatase, catalase, dehydrogenase and alkaline phosphatase, that were essential for cycling of $\mathrm{C}, \mathrm{N}, \mathrm{P}$, and $\mathrm{S}$ in the soils, under different soil metal contents. The appropriate enzyme(s) for assessing bioavailability of heavy metal contaminated soils was identified. A quantitative cause-effect model describing enzyme activities versus chemical and physical attributes of heavy metals contaminated soils was established. The results enrich and provide a more solid basis for soil enzyme activity based assessment of heavy metal bioavailability.

\section{Materials and methods}

\subsection{Experimental design}

Soil samples for this study were taken from a comprehensive soil investigation in which 233 sampling sites were evenly selected within the 5th ring road of Beijing (Wang et al., 2012a,b). In total, 40 surface soil samples $(0-20 \mathrm{~cm})$ were selected. These soils belonged to the same pedological series but were different in properties due to the land use patterns such as farmland, meadow, woodland, wasteland, housing and roadside over an area of $667 \mathrm{~km}^{2}$.
In the first batch experiment (designated as Exp. 1 hereafter), three soils that had similar properties other than SOM were used (Table 1). The three soils represents the low (Soil 3, of $0.82 \%$ ), middle (Soil 2, of 1.72\%) and high (Soil 1, of 2.91\%) SOM content, respectively, in the study region. Soil $\mathrm{pH}$ is the other factor that may have significant impacts on soil heavy metal bioavailability thus the soil enzyme activities. To avoid the potential interaction between SOM and soil $\mathrm{pH}$, the three soils used in Exp. 1 had quite similar soil pH around 8.2. Exp. 1 was intended to identify one (or more) enzymes and metal pollutants whose activities were appropriate indicators of heavy metal pollution in soils. It was designed as a two-factor completely randomized block in triplicates with four separate heavy metal treatments (control, $\mathrm{Pb}, \mathrm{Cd}$, and $\mathrm{As}$ ) and three soil treatments. For metal treatments, solution of $\mathrm{Pb}\left(\mathrm{CH}_{3} \mathrm{COO}\right)_{2}, \mathrm{Na}_{3} \mathrm{AsO}_{4}$, or $\mathrm{Cd}\left(\mathrm{NO}_{3}\right)_{2}$ was incorporated into soils to achieve the Grade III metal contamination levels of the Chinese Environmental Quality Standard for Soils, which is 500, 50, and $1 \mathrm{mg} \mathrm{kg}^{-1}$, respectively, for $\mathrm{Pb}$, As and $\mathrm{Cd}$. The soils were then incubated for a month before used for enzyme activity analysis (Table 2).

The second batch experiment designated as Exp. 2 hereafter involved the remaining thirty-seven soils (Table 1) and was intended to elaborate activities of the indicator enzyme (identified from the outcomes of Exp. 1) in soils of different organic matter contents that were exposed to the same heavy metal contamination levels. The outcomes were used to establish the quantitative relationship between activities of the indicator enzyme and corresponding soil organic matter contents, ranging from $0.27 \%$ to $6.58 \%$. The experiment was a two-factor randomized complete block in triplicate with two heavy metal treatments (control and indicator metal, $\mathrm{Pb}$ in this case) and 37 soils. Similar to Exp. 1, the selected soils was spiked with $\mathrm{Pb}\left(\mathrm{CH}_{3} \mathrm{COO}\right)_{2}$ to achieve the contamination level of $500 \mathrm{mg} \mathrm{Pb} \mathrm{kg}^{-1}$ soil, and then incubated for a month before enzyme activity analysis.

\subsection{Soil properties and enzyme activity analysis}

Soils were air-dried and crushed to pass through a sieve with $2 \mathrm{~mm}$ openings for determining soil texture and $\mathrm{pH}$. A quarter of each sieved specimen was further ground to pass through a sieve

Table 1

Properties of soils included in Exp. 1 and 2.

\begin{tabular}{|c|c|c|c|c|c|c|c|}
\hline Soil & Clay (\%) & Slit (\%) & Sand (\%) & $\mathrm{pH}^{\mathrm{a}}$ & $\mathrm{CEC}\left(\mathrm{cmol} \mathrm{kg}^{-1}\right)$ & $\operatorname{SOM}^{\mathrm{b}}(\%)$ & $\mathrm{Pb}^{\mathrm{C}}\left(\mathrm{mg} \mathrm{kg}^{-1}\right)$ \\
\hline Exp. 1-Soil 1 & 3.59 & 52.3 & 44.1 & 8.21 & 9.90 & 2.91 & 16.4 \\
\hline Exp. 1-Soil 2 & 3.20 & 61.5 & 35.3 & 8.18 & 11.5 & 1.72 & 29.8 \\
\hline Exp. 1-Soil 3 & 2.87 & 47.2 & 49.9 & 8.62 & 7.50 & 0.84 & 16.7 \\
\hline Exp. $2^{d}$ & $\begin{array}{l}1.24 \\
(0.56-2.17)\end{array}$ & $\begin{array}{l}60.3 \\
(49.8-76.9)\end{array}$ & $\begin{array}{l}38.5 \\
(21.8-49.4)\end{array}$ & $\begin{array}{l}7.76 \\
(6.04-8.10)\end{array}$ & $\begin{array}{l}12.0 \\
(8.25-17.3)\end{array}$ & $\begin{array}{l}2.17 \\
(0.27-6.58)\end{array}$ & $\begin{array}{l}19.2 \\
(1.97-57.8)\end{array}$ \\
\hline
\end{tabular}

a Soil:water 1:2.5

b Soil organic matter.

c Background concentration.

d Average and range of 37 soil samples.

Table 2

Methods of soil enzyme activity assays.

\begin{tabular}{|c|c|c|c|c|c|}
\hline Enzyme & Substrate & Incubation $(\mathrm{h})$ & Metabolite & Unit & References \\
\hline Invertase & 3,5-Dinitrosalicylic acid & 12 & Glucose & mg glucose $\mathrm{g}^{-1}$ soil $12 \mathrm{~h}^{-1}$ & Frankeberger and Johanson (1983) \\
\hline Urease & Urea & 3 & $\mathrm{NH}_{4}-\mathrm{N}$ & $\mathrm{mg} \mathrm{NH}{ }^{4}-\mathrm{N} \mathrm{g}^{-1}$ soil $3 \mathrm{~h}^{-1}$ & Gosewinkel and Broadbent (1984) \\
\hline Arylsulfatase & $\begin{array}{l}\text { Potassium 4-Nitrophenyl } \\
\text { sulfate }\end{array}$ & 3 & p-Nitrophenol & $\mu \mathrm{g}$ p-nitrophenol $\mathrm{g}^{-1}$ soil $3 \mathrm{~h}^{-1}$ & Tabatabai and Bremner (1970) \\
\hline Catalase & $\mathrm{H}_{2} \mathrm{O}_{2}$ & 0.3 & $\mathrm{H}_{2} \mathrm{O}$ & $\mathrm{mg} \mathrm{H}_{2} \mathrm{O} \mathrm{g}^{-1}$ soil $0.3 \mathrm{~h}^{-1}$ & Johnson and Temple (1964) \\
\hline Dehydroenase & $\begin{array}{l}\text { 2,3,5-Triphenyltretrasolium } \\
\text { (TTC) }\end{array}$ & 15 & $\begin{array}{l}\text { Triphenyl } \\
\text { formazance (TPF) }\end{array}$ & ng TPF g ${ }^{-1}$ soil $15 \mathrm{~h}^{-1}$ & Stevenson (1959) \\
\hline Alkaline phosphatase & $\mathrm{C}_{6} \mathrm{H}_{5} \mathrm{PO}_{4} \mathrm{Na}_{2} \cdot 2 \mathrm{H}_{2} \mathrm{O}$ & 1 & Phenol & $\mu \mathrm{g}$ phenol $\mathrm{g}^{-1}$ soil $1 \mathrm{~h}^{-1}$ & Kramer and Yerdei (1959) \\
\hline
\end{tabular}


with $0.1 \mathrm{~mm}$ openings for determining cation exchange capacity (CEC), organic carbon and heavy metal contents.

For the soil texture analysis, the clay, silt and sand contents of soils were determined by a laser diffraction system (Malvern Master Sizer 2000, Malvern Co., England) after the soil particles were dispersed in $0.5 \mathrm{M} \mathrm{NaPO}_{3}$. The soil $\mathrm{pH}$ was determined at a soilto-water ratio of $1: 2.5$. The CEC was measured by the ammonium acetate method (Gillman et al., 1983). The soil organic carbon (SOC) contents were determined by a dry combustion method with an elemental analyzer (Vario EL III, Elementar, Hanau Germany), using soil pretreated with $\mathrm{HCl}$, and in turn the soil organic matter content equaled $1.724 \times$ SOC (Nam et al., 2008). For soil metal content analysis, samples were first digested using a four acid mixture containing $10 \mathrm{ml} \mathrm{HCl}, 5 \mathrm{ml} \mathrm{HNO}_{3}, 5 \mathrm{ml} \mathrm{HF}$, and $3 \mathrm{ml} \mathrm{HClO} 4$, and then analyzed by ICP-MS for Pb and Cd or by ICP-AES for As.

For soil enzyme activity assays, soils were first prepared as described in the previous section. Then, the soils were incubated in $250 \mathrm{ml}$ flasks, at $25{ }^{\circ} \mathrm{C}$ and $10 \% \mathrm{w} / \mathrm{w}$ water content for 5 weeks. Afterwards, aliquots of soils ( $1 \mathrm{~g}, 2 \mathrm{~g}$ or $5 \mathrm{~g}$ ) were incubated in $50 \mathrm{ml}$ flasks for different times $(20 \mathrm{~min}, 1 \mathrm{~h}, 3 \mathrm{~h}, 12 \mathrm{~h}$ or $15 \mathrm{~h}$ ), depending on the target soil enzyme assayed. Six key enzymes involved in soil nutrient cycling were selected for study.

The enzyme activities were assayed according to the principle of incubating an aliquot of soil with a substrate for reaction for a given period of time then measuring the amount of metabolite produced. The substrate, incubation time, metabolite and unit expression along with the reference sources of the enzyme activities measured are summarized in Table 3.

Control tests without soil and substrate were conducted to evaluate the errors caused by reagent impurities and background values of the substrates.

\subsection{Data analyses}

Effects of metals and soils on the soil enzyme activities were analyzed using the ANOVA. Effects of a single factor (i.e. heavy metal or soil) and their interaction on soil enzyme activities were analyzed using software of DPS (Data Processing System). Main effects on treatment means were separated according to Tukey's test at the $p=0.05$ level. Correlations of enzyme activity and soil property were calculated by SPSS (Statistical Product and Service Solution, version 18.0), and the significance level reported $(p<0.01$ and $p<0.05)$ was based on the Pearson's coefficients. The indicator enzyme activities versus soil organic matter contents were fitted to a logarithmic function using the non-linear curve fit approach of Origin Pro 8 (Origin Lab Corporation, 2007).

To compare the effects among soils with different properties, a dimensionless parameter, enzyme activity change ratio (ACR), was introduced.

$\mathrm{ACR}=\left(A_{h}-A_{c}\right) / A_{c} \times 100 \%$

$A_{h}$ and $A_{c}$ denote enzyme activity of metal-polluted and control soils, respectively. ACR depicts the relative toxicity level of a heavy metal to enzyme activity in the polluted soil.

\section{Results and discussion}

\subsection{Screening of sensitive indicator(s)}

In Exp. 1, severely polluted soils were used to look for soil enzymes that were most susceptible to heavy metal toxicities. Contamination levels of the experimental soils were set to equal the Grade III thresholds given by the Chinese Environmental Quality Standard for Soil. This represented a severe heavy metal pollution scenario that might cause damage to soil enzyme activities.

Table 3 summarizes the soil enzyme activities of $\mathrm{Pb}-$, As-, and $\mathrm{Cd}$-polluted soils. Judging by the ranges, medians and means, the enzyme activities of the $\mathrm{Pb}-$, As-, or Cd-polluted soils did not appear to be damaged. The ranges reflected the extent to which land uses and metal pollutions altered the microbial metabolisms of indigenous soil ecosystems.

The ANOVA of Exp. 1 did not yield a consistent pattern as to how the enzymes fare in the metal-polluted soils (Table 4). It showed that some but not all of the enzyme activities of soils were significantly affected by some of the metal pollutions. For example, $\mathrm{Pb}$ pollution at $500 \mathrm{mg} \mathrm{kg}^{-1}$ caused activity changes of invertase and dehydrogenase, while no enzyme activity was found to be affected by As pollution at $50 \mathrm{mg} \mathrm{kg}^{-1}$ and $\mathrm{Cd}$ pollution at $1 \mathrm{mg} \mathrm{kg}^{-1}$. Variation of soil was found to be related to activity changes of urease, arylsulfatase and alkaline phosphatase.

To place the changes in enzyme activities on the same scale for comparison, the data was transformed according to Eq. (1) to ACR (the activity change ratio), which varied from -56 to $89,-24$ to 63 , and -23 to 65 for $\mathrm{Pb}, \mathrm{As}$, and $\mathrm{Cd}$, respectively (Table 5). The positive ACRs denoted that the enzyme activity was enhanced and the negative ACRs denoted that enzyme activity was reduced due to metal pollutions. For Pb-polluted soils, the ACRs of all six enzymes lined up in descending order such that Soil $1>$ Soil $2>$ Soil 3. It appeared that certain common attributes across these three soils yielded reactions resulting in enzyme activities rising or falling in

Table 4

ANOVA analysis of enzyme activities in heavy metal polluted soils with different properties.

\begin{tabular}{lllllll}
\hline Factor & $\mathrm{IN}^{\mathrm{a}}$ & $\mathrm{UR}^{\mathrm{b}}$ & $\mathrm{ASL}^{\mathrm{C}}$ & $\mathrm{CAT}^{\mathrm{d}}$ & $\mathrm{DEH}^{\mathrm{e}}$ & $\mathrm{ALP}^{\mathrm{f}}$ \\
\hline $\mathrm{Pb}$ & $0.002^{* *}$ & 0.990 & 0.988 & 0.662 & $0.004^{* *}$ & 0.121 \\
Soil & 0.730 & $0.003^{* *}$ & $0.000^{* *}$ & 0.391 & 0.099 & $0.001^{* *}$ \\
$\mathrm{~Pb} \times$ Soil & $0.000^{* *}$ & $0.000^{* *}$ & $0.002^{* *}$ & $0.037^{*}$ & 0.136 & $0.000^{* *}$ \\
$\mathrm{Cd}$ & 0.347 & 0.687 & 0.824 & 1.100 & 0.865 & 0.154 \\
Soil & 0.730 & $0.003^{* *}$ & $0.000^{* *}$ & 0.391 & 0.099 & $0.000^{* *}$ \\
Cd $\times$ Soil & 0.5236 & 0.129 & $0.000^{* *}$ & $0.007^{* *}$ & $0.009^{* *}$ & 0.207 \\
As & 0.136 & 0.887 & $0.002^{* *}$ & 0.469 & 0.051 & $0.026^{*}$ \\
Soil & 0.730 & $0.003^{* *}$ & $0.000^{* *}$ & 0.391 & 0.099 & $0.000^{* *}$ \\
As $\times$ Soil & $0.000^{* *}$ & 0.583 & $0.017^{*}$ & 0.165 & 0.487 & 0.799 \\
\hline
\end{tabular}

a Invertase.

b Urease.

c Arylsulfatase.

d Catalase.

e Dehydrogenase.

${ }^{\mathrm{f}}$ Alkaline phosphatase.

* There is a significant difference caused by factor.

** There is a very significant difference caused by factor.

Table 3

Soil enzyme activities of $\mathrm{Pb}\left(500 \mathrm{mg} \mathrm{kg}^{-1}\right)$, As (50 $\left.\mathrm{mg} \mathrm{kg}^{-1}\right)$, and $\mathrm{Cd}\left(1 \mathrm{mg} \mathrm{kg}^{-1}\right)$ polluted soils. ${ }^{\text {a }}$

\begin{tabular}{|c|c|c|c|c|c|c|}
\hline Treatment & Invertase & Urease & Arylsulfatase & Catalase & Dehydrogenase & Alkaline phosphatase \\
\hline Control & $126.9 \pm 35.9$ & $2579 \pm 656$ & $71.3 \pm 12.6$ & $29.6 \pm 1.87$ & $245 \pm 64.9$ & $847 \pm 265$ \\
\hline $\mathrm{Pb}$ & $116.1 \pm 42.0$ & $2691 \pm 1067$ & $73.0 \pm 22.8$ & $28.8 \pm 1.92$ & $396 \pm 138.6$ & $770 \pm 394$ \\
\hline As & $116.1 \pm 25.5$ & $2653 \pm 599$ & $72.2 \pm 13.7$ & $28.6 \pm 2.53$ & $230 \pm 58.5$ & $704 \pm 210$ \\
\hline $\mathrm{Cd}$ & $121.9 \pm 37.3$ & $2753 \pm 883$ & $75.8 \pm 28.4$ & $29.8 \pm 1.97$ & $260 \pm 90.8$ & $752 \pm 256$ \\
\hline
\end{tabular}

a Unit for different enzyme see Table 2, data for mean and standard deviation. 
Table 5

Multiple comparison of enzyme activity change ratios in three soils with $\mathrm{Pb}, \mathrm{Cd}$ and As treatment.

\begin{tabular}{|c|c|c|c|c|c|c|c|}
\hline Heavy metal & Soil no. & IN (\%) & UR (\%) & ASL (\%) & CAT (\%) & DEH (\%) & ALP (\%) \\
\hline $\mathrm{Pb}$ & $\begin{array}{l}1 \\
2 \\
3\end{array}$ & $\begin{array}{r}-8.67 \mathrm{a} \\
0.57 \mathrm{a} \\
-24.7 \mathrm{~b}\end{array}$ & $\begin{array}{r}16.3 \mathrm{a} \\
14.9 \mathrm{a} \\
-27.0 \mathrm{~b}\end{array}$ & $\begin{array}{c}36.2 \mathrm{a} \\
-7.68 \mathrm{~b} \\
-20.6 \mathrm{~b}\end{array}$ & $\begin{array}{r}3.35 \mathrm{a} \\
-6.67 \mathrm{~b} \\
-4.25 \mathrm{ab}\end{array}$ & $\begin{array}{l}89.4 \mathrm{a} \\
49.7 \mathrm{a} \\
37.0 \mathrm{a}\end{array}$ & $\begin{array}{r}0.86 a \\
16.3 a \\
-55.9 b\end{array}$ \\
\hline $\mathrm{Cd}$ & $\begin{array}{l}1 \\
2 \\
3\end{array}$ & $\begin{array}{l}-1.75 a \\
-4.77 a \\
-6.69 a\end{array}$ & $\begin{array}{c}15.2 \mathrm{a} \\
1.04 \mathrm{a} \\
-0.91 \mathrm{a}\end{array}$ & $\begin{array}{r}57.2 \mathrm{a} \\
-12.8 \mathrm{~b} \\
-23.0 \mathrm{~b}\end{array}$ & $\begin{array}{r}0.45 a b \\
7.83 a \\
-4.98 b\end{array}$ & $\begin{array}{c}-20.9 \mathrm{~b} \\
-9.20 \mathrm{~b} \\
65.4 \mathrm{a}\end{array}$ & $\begin{array}{l}-8.69 \mathrm{a} \\
-5.50 \mathrm{a} \\
22.4 \mathrm{a}\end{array}$ \\
\hline As & $\begin{array}{l}1 \\
2 \\
3\end{array}$ & $\begin{array}{r}-6.85 b \\
-20.10 \mathrm{c} \\
9.40 \mathrm{a}\end{array}$ & $\begin{array}{r}-0.12 \mathrm{a} \\
7.88 \mathrm{a} \\
2.26 \mathrm{a}\end{array}$ & $\begin{array}{c}31.5 \mathrm{a} \\
-23.6 \mathrm{~b} \\
1.37 \mathrm{ab}\end{array}$ & $\begin{array}{l}-7.93 \mathrm{a} \\
-0.78 \mathrm{a} \\
-0.96 \mathrm{a}\end{array}$ & $\begin{array}{l}-2.61 \mathrm{a} \\
18.4 \mathrm{a} \\
62.7 \mathrm{a}\end{array}$ & $\begin{array}{r}15.2 \mathrm{a} \\
21.4 \mathrm{a} \\
-14.5 \mathrm{a}\end{array}$ \\
\hline
\end{tabular}

There is no significant difference among ratios followed by the same letter $(p<0.05)$.

Table 6

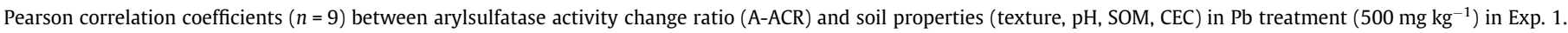

\begin{tabular}{|c|c|c|c|c|c|c|c|}
\hline & A-ACR (\%) & Clay (\%) & Silt (\%) & Sand (\%) & $\mathrm{pH}$ & SOM (\%) & $\mathrm{CEC}\left(\mathrm{cmol} \mathrm{kg}^{-1}\right)$ \\
\hline A-ACR (\%) & 1 & $0.760^{\mathrm{a}}$ & 0.040 & -0.77 & -0.495 & $0.767^{a}$ & 0.257 \\
\hline Clay (\%) & & 1 & 0.304 & -0.348 & $-0.806^{\mathrm{b}}$ & $0.999^{\mathrm{b}}$ & 0.557 \\
\hline Silt (\%) & & & 1 & $-0.999^{\mathrm{b}}$ & $-0.808^{\mathrm{b}}$ & 0.269 & $0.960^{\mathrm{b}}$ \\
\hline Sand (\%) & & & & 1 & $0.835^{\mathrm{b}}$ & -0.314 & $-0.972^{\mathrm{b}}$ \\
\hline $\mathrm{pH}$ & & & & & 1 & $-0.785^{\mathrm{b}}$ & $-0.940^{\mathrm{b}}$ \\
\hline SOM (\%) & & & & & & 1 & 0.527 \\
\hline $\mathrm{CEC}\left(\mathrm{cmol} \mathrm{kg}^{-1}\right)$ & & & & & & & 1 \\
\hline
\end{tabular}

a Correlation is significant at the 0.05 level.

b Correlation is significant at the 0.01 level.

a proportional manner. As showed by Table 1, SOM and clay content were two soil attributes that have same descending pattern of the six enzyme activities. Given that the variation of clay content was much smaller than that of SOM, SOM was thought to be the main factor driving the changes of soil enzyme activity. For Cdand As-polluted soils, the ACRs of the enzymes in the soils did not exhibit a consistent rise and fall pattern. Therefore, $\mathrm{Pb}$ stood out as representative of the effect of soil pollution on enzyme activities. Furthermore, among the six soil enzymes, the ACRs of arylsulfatase emerged to indicate it as the enzyme whose ACRs in soils rise and fall in a consistent manner across all three metal pollutants except for one point for As. Accordingly in Exp. 2, we chose pollutant $\mathrm{Pb}$ at $500 \mathrm{mg} \mathrm{kg}^{-1}$ and examined how the activity of arylsulfatase changes across the remaining 37 soils.

\subsection{Arylsulfatase activity change ratios of Pb-polluted soils: influence of soil properties}

In Exp. 2, we sought the activity change ratios of arylsulfatase (A-ACR) in $37 \mathrm{~Pb}$-polluted soils and their relationship to the inherent soil properties. Organic matter and clay contents of the soils significantly affected the A-ACRs of the polluted soils (Table 6) and the correlation coefficients were 0.767 and 0.760 , respectively. The influences of other soil properties on arylsulfatase in soils were not significant. In the meantime, the soils' clay contents were found to be significantly correlated to the corresponding organic matter contents $(r=0.999, p<0.001)$. Through multiple comparisons of the A-ACRs involving data in Tables 1 and 6 , we concluded that the A-ACRs of $\mathrm{Pb}$ polluted soil should be quantitatively correlated to SOM content.

Data from Exp. 2 was fitted to the following Logarithmic function:

$y=a+b \ln (x+c)$

where $y$ represents A-ACR (in\% of control), $x$ represents soil organic matter content (\%) and $a, b$, and $c$ are equation parameters to be determined through nonlinear regression. Hypothetically, the parameter " $a$ " represents the A-ARC when the soil organic matter content is zero. Within the range of organic matter content from $0.27 \%$ to $6.58 \%$ in 37 soils, the resulting model shows that A-ACRs increase exponentially with the rise of soil organic matter content (Fig. 1) with $R^{2}=0.7073$ :

$$
\mathrm{A}-\mathrm{ACR}_{\mathrm{Pb}}=-18.5+21.4 x \ln (\mathrm{SOM}-0.05)
$$

where $A-A C R_{\mathrm{Pb}}$ is the activity change ratios of arylsulfatase of $\mathrm{Pb}$ polluted soils (500 $\mathrm{mg} \mathrm{kg}^{-1}$ in this study), and SOM denotes the organic matter content of soil (\%).

When the soil organic matter content was low, according to Eq. (3), the heavy metal pollution would have devastating effects on the soil microbial communities by inhibiting the soil enzyme activities and thus the microbial metabolisms of the soil. When the organic matter level of the soils rose, the metal pollution's inhibiting effects on soil enzyme activities would gradually subside and eventually elevate to the range where the soil enzyme activities were being enhanced (Fig. 1). In this regard, two points on the curve were significant. The apex of the curve, marked as " $\mathrm{A}$ " in Fig. 1 , is the demarcation of the change in $A-A_{C B}\left(\triangle A-A C R_{P b}\right)$ versus change in soil organic matter content $(\triangle S O M)$ below which the $A-A_{P b}$ dropped rapidly to show devastating harm to soil enzyme activity due to decreasing soil organic matter content, and beyond which $\mathrm{A}-\mathrm{ACR}_{\mathrm{Pb}}$ showed gradually recovery of soil enzyme activity due to rising soil organic matter content (Fig. 1). In this study, the SOM at point A was $1.05 \%$. The point, marked as B in Fig. 1, represented the soil organic content that was needed to protect the soils from the harm of heavy metal pollution (Fig. 1) because the $\mathrm{A}-\mathrm{ACR} \mathrm{Pb}_{\mathrm{Pb}}=0$ and the arylsulfatase activity in polluted soil equaled that in the control soil. In this study, the threshold SOM $\mathrm{B}=2.42 \%$ for $\mathrm{Pb}$ pollution at $500 \mathrm{mg} \mathrm{kg}^{-1}$, below which the $\mathrm{Pb}$ pollution has harmful effects on soil enzyme activities and therefore the soil microbial communities, and beyond which the soil organic matter contents are able to enhance the soil enzyme activities and protect the soil microbial community from the harm of $\mathrm{Pb}$ pollution. 
Fitting Analysis of A-ACR to 37 soils with different SOM

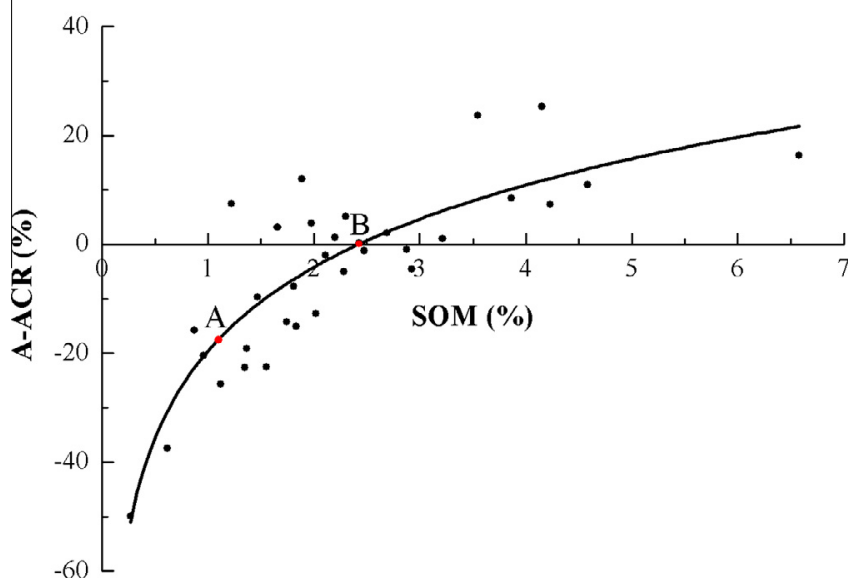

Fig. 1. Change trend of arylsulfatase activity change ratio in 37 different soil organic matter contents. A is the critical point of growth rate. B is the critical point of toxic effect ( $\mathrm{Pb} 500 \mathrm{mg} \mathrm{kg}^{-1}$ ).

\section{Conclusions}

We conducted two experiments and used the results to elaborate how soil enzymatic activity might be employed to quantify the impacts of heavy metals on polluted soils. The major findings are:

(1) Soil properties had significant effects on the activities of soilborne enzymes in heavy metal polluted soils. Among six soil enzymes depicting the cycling of C, N, P, and S in soil, arylsulfatase was the most sensitive indicator for the adverse impacts of Pb-, As-, and Cd-polluted soils. At the severe soil contamination level (500, 50 and $1 \mathrm{mg} \mathrm{kg}^{-1}$, respectively for $\mathrm{Pb}, \mathrm{As}$, and $\mathrm{Cd}$ ), $\mathrm{Pb}$ exhibit a consistent pattern on arylsulphatase activity and stood out as representative of the effect of soil heavy metal pollution on enzyme activities.

(2) Based on the results of the subsequent experiment, a quantitative model was derived to predict the changes of arylsulfatase activity with SOM content. The arylsulfatase activities in $\mathrm{Pb}$ pollution soils are marked by two notable attributes: (a) The soil needed to contain at least $2.42 \%$ (critical point $B$ in the model of organic matter to protect its microbial community from the harm of the $\mathrm{Pb}$ pollution (at $500 \mathrm{mg} \mathrm{kg}^{-1}$ in our study), and (b) when the soil organic matter content was less than $1.05 \%$ (critical point $\mathrm{A}$ in the model) the arylsulfatase activity dropped rapidly, indicating the soil microbial community was experiencing devastating harm due to the $\mathrm{Pb}$ pollution. When the soil organic matter content was greater than $1.05 \%$, the arylsulfatase activity gradually rose to higher levels, showing that instead of harm the soil microbial activities were enhanced.

(3) The quantitative model was derived under the conditions of our specific soil properties range. Further researches under wider range of soil properties and different soil types were needed to integrate the quantitative relationship into ecological risk assessment of soil heavy metal pollution. For instance, soils used in this study limits to silt loam and sandy loam, and soil pH is over 6.0. Anyhow, the model illustrated the offset of soil organic matter to heavy metal toxicity on soil enzymes activities and could be used to explain the contradictory finding in existing literature on soil enzymes activities under various heavy metal pollution and soil properties.

\section{Acknowledgement}

The work was supported by a grant received from the National Natural Science Foundation of China (41173123).

\section{References}

Badiane, N.N.Y., Chotte, J.L., et al., 2001. Use of soil enzyme activities to monitor soil quality in natural and improved fallows in semi-arid tropical regions. Appl. Soil Ecol. 18 (3), 229-238.

Baker, L.R., White, P.M., et al., 2011. Changes in microbial properties after manure lime, and bentonite application to a heavy metal-contaminated mine waste. Appl. Soil Ecol.

Carlon, C., Dalla Valle, M., et al., 2004. Regression models to predict water-soil heavy metals partition coefficients in risk assessment studies. Environ. Pollut. 127 (1), 109-115.

Chaperon, S., Sauve, S., 2007. Toxicity interaction of metals (Ag, Cu, Hg, Zn) to urease and dehydrogenase activities in soils. Soil Biol. Biochem. 39 (9), 2329-2338.

D'Ascoli, R., Rao, M.A., et al., 2006. Impact of river overflowing on trace element contamination of volcanic soils in south Italy: Part II. Soil biological and biochemical properties in relation to trace element speciation. Environ. Pollut. 144 (1), 317-326.

Doelman, P., Haanstra, L., 1986. Short- and long-term effects of heavy metals on urease activity in soils. Biol. Fertil. Soils 2 (4), 213-218.

Doran, J., Safley, M., et al., 1997. Defining and assessing soil health and sustainable productivity. Biol. Indic. Soil Health, 1-28.

Effron, D., de la Horra, A.M., et al., 2004. Effect of cadmium, copper, and lead on different enzyme activities in a native forest soil. Commun. Soil Sci. Plant Anal. 35 (9-10), 1309-1321.

Filip, Z., 2002. International approach to assessing soil quality by ecologicallyrelated biological parameters. Agric. Ecosyst. Environ. 88 (2), 169-174.

Frankeberger, W., Johanson, J., 1983. Method of measuring invertase activity in soils. Plant and Soil 74 (3), 301-311.

Gillman, G.P., Bruce, R.C., et al., 1983. A comparison of methods used for determination of cation exchange capacity. Commun. Soil Sci. Plant Anal. 14 (11), 1005-1014.

Gosewinkel, U., Broadbent, F., 1984. Conductimetric determination of soil urease activity. Commun. Soil Sci. Plant Anal. 15 (11), 1377-1389.

Haberern, J., 1992. A soil health index. J. Soil Water Conserv. 47 (1), 6.

Hinojosa, M.B., Carreira, J.A., et al., 2004. Soil moisture pre-treatment effects on enzyme activities as indicators of heavy metal-contaminated and reclaimed soils. Soil Biol. Biochem. 36 (10), 1559-1568.

Johnson, J.L., Temple, K.L., 1964. Some variables affecting the measurement of "catalase activity" in soil1. Soil Sci. Soc. Am. J. 28 (2), 207-209.

Karaca, A., Turgay, O., et al., 2006. Effects of a humic deposit (gyttja) on soil chemical and microbiological properties and heavy metal availability. Biol. Fertil. Soils 42 (6), 585-592.

Khan, S., Cao, Q., et al., 2007. Soil enzymatic activities and microbial community structure with different application rates of Cd and Pb. J. Environ. Sci. 19 (7), $834-840$

Kramer, M., Yerdei, G., 1959. Application of the method of phosphatase activity determination in agricultural chemistry. Soviet Soil Sci. 9, 1100-1103.

Kunito, T., Saeki, K., et al., 2001. Copper and zinc fractions affecting microorganisms in long-term sludge-amended soils. Bioresour. Technol. 79 (2), 135-146.

Mora, A.P.d., Ortega-Calvo, J.J., et al., 2005. Changes in enzyme activities and microbial biomass after "in situ" remediation of a heavy metal-contaminated soil. Appl. Soil Ecol. 28 (2), 125-137.

Moreno, J.L., García, C., et al., 2003. Toxic effect of cadmium and nickel on soil enzymes and the influence of adding sewage sludge. Eur. J. Soil Sci. 54 (2), $377-$ 386.

Nam, J.J., Thomas, G.O., et al., 2008. PAHs in background soils from Western Europe: Influence of atmospheric deposition and soil organic matter. Chemosphere 70 (9), 1596-1602.

Oliveira, A., Pampulha, M.E., 2006. Effects of long-term heavy metal contamination on soil microbial characteristics. J. Biosci. Bioenegry 102 (3), 157-161.

Sauve, S., Hendershot, W., et al., 2000. Solid-solution partitioning of metals in contaminated soils: dependence on $\mathrm{pH}$, total metal burden, and organic matter Environ. Sci. Technol. 34 (7), 1125-1131.

Stevenson, I.L., 1959. Dehydrogenase activity in soil. Can. J. Microbiol. 5 (2), 229235.

Tabatabai, M., Bremner, J., 1970. Arylsulfatase activity of soils. Soil Sci. Soc. Am. J. 34 (2), 225-229.

Wang, M.E., Chen, W.P., Markert, B., Peng, C., Ouyang, Z.Y., 2012a. A GIS technology based potential eco-risk assessment of metals in urban soils in Beijing, China. Environ. Pollut. 161, 235-242.

Wang, M.E., Markert, B., Chen, W.P., Peng, C., Ouyang, Z.Y., 2012b. Identification of heavy metal pollutants using multivariate analysis and effects of land uses on their accumulation in urban soils in Beijing, China. Environ. Monit. Assess. 184, 5889-5897.

Wang, Y., Li, Q., et al., 2008. Assessment of microbial activity and bacterial community composition in the rhizosphere of a copper accumulator and a nonaccumulator. Soil Biol. Biochem. 40 (5), 1167-1177. 